\title{
GAMBARAN FAKTOR YANG MEMPERNGARUHI PENERIMAAN DIRI ORANGTUA YANG MEMILIKI ANAK AUTISME
}

\author{
Selvi ${ }^{1)}$, Shanty Sudarji ${ }^{2)}$ \\ Program Studi Psikologi Universitas Bunda Mulia \\ ${ }^{1}$ Selvigreen13@gmail.com, ${ }^{2}$ gbu120711@gmail.com
}

\begin{abstract}
People with autism has problems such as talking and understanding, and usually they have difficulty interacting with others and the environment. When they were diagnosed with autism, they will have feelings of shock, sadness, worry, embarrassment and fear. To be able to accept the state of autism children needed selfacceptance, This research can be done to determine what factors that can affect a person. This method uses qualitative method of phenomenology type with observation method and result to collect data. The study was conducted on five parents who have children with autism, where children and parents live together. The results of this study can be concluded that factors that are not owned by the subject $K$ is the pattern of care in childhood is good, the effect of success experienced. Factors that Subject D does not have are obstacles in the environment, the impact of success experienced, the self-concept is stable. Factors that are not owned by $H$ is the effect of success experienced, the pattern of foster in childhood is good, stable self-concept. Factors that are not owned by $N$ is the influence of success that occurs and the pattern of foster in good times are good. While T has fulfilled all ten factors.
\end{abstract}

Keywords: Autism, Factors that influence self-acceptance, Parents

\begin{abstract}
ABSTRAK
Autisme memiliki masalah dalam berbicara dan memahami sesuatu, dan biasanya mereka mengalami kesulitan untuk berinteraksi dengan orang lain serta lingkungan. Biasanya saat orangtua mengetahui bahwa anak mereka terdiagnosa autisme, mereka akan memiliki perasaan kaget, sedih, khawatir, malu dan takut. Untuk dapat menerima keadaan anak autisme dibutuhkan penerimaan diri, Penelitian ini bertujuan untuk mengetahui faktor-faktor apa saja yang dapat mempengaruhi penerimaan diri seseorang.Penelitian ini menggunakan metode penelitian wawancara kualitatif jenis fenomenologi dengan metode observasi dan wawancara untuk mengumpulkan data. Penelitian dilakukan kepada lima orang tua yang memiliki anak dengan autisme, dimana anak dan orang tua tinggal bersama.Hasil penelitian ini dapat disimpulkan bahwa Faktor yang tidak dimiliki oleh subjek K adalah pola asuh di masa kecil yang baik, pengaruh keberhasilan yang dialami. Faktor yang tidak dimiliki Subjek D adalah hambatan di lingkungan, pengaruh keberhasilan yang dialami, konsep diri yang stabil. Faktor yang tidak dimiliki oleh $\mathrm{H}$ adalah pengaruh keberhasilan yang dialami, pola asuh di masa kecil yang baik, konsep diri yang stabil. Faktor yang tidak dimiliki oleh $\mathrm{N}$ adalah pengaruh keberhasilan yang dialami dan pola asuh dimasa kecil yang baik. Sedangkan $\mathrm{T}$ sudah memenuhi kesepuluh faktor yang ada. Kata kunci : Autisme, Faktor-faktor yang mempengaruhi penerimaan diri
\end{abstract}

Kata kunci: Autisme, Faktor penerimaan diri, Orangtua 


\section{PENDAHULUAN}

Anak berkebutuhan khusus di Indonesia dari tahun ke tahun terus meningkat (NN, 2013). Menurut Kementrian Pemberdayaan Perempuan dan Perlindungan Anak tahun 2013, jumlah anak berkebutuhan khusus yang berhasil di data ada sekitar 1,5 juta jiwa. Secara umum, Perserikatan Bangsa Bangsa (PBB) memperkirakan bahwa paling sedikit ada 10 persen anak usia sekolah yang memiliki kebutuhan khusus. Di Indonesia, jumlah anak usia sekolah, yaitu 5-14 tahun, ada sebanyak 42,8 juta jiwa. Jika mengikuti perkiraan tersebut, maka diperkirakan ada kurang lebih 4,2 juta anak Indonesia yang berkebutuhan khusus (Harwono, 2013).

Kauffman \& Hallahan (dalam Delphie, 2006) menjelaskan bahwa salah satu kebutuhan khusus yang menyita perhatian orangtua adalah autisme.Berdasarkandata dari Badan Penelitian Statistik (BPS) Sejak tahun 2010 dengan perkiraan hingga tahun 2016, terdapat sekitar 140.000 anak di bawah usia 17 tahun yang menyandang autisme. Perkembangan autisme di Indonesia setiap tahun semakin meningkat. Pada awal tahun 2000-an prevalensinya sekitar 1:1000 kelahiran, penelitian pada tahun 2008 menunjukkan peningkatan hingga 1,68:1000 kelahiran, tahun 2010 dengan perkiraan hingga tahun 2016, terdapat sekitar 140 ribu anak di bawah usia 17 tahun menyandang autisme (Kurnia,2015).

Reaksi pertama yang muncul dari orang tua ketika mengetahui anaknya terdiagnosa autisme adalah perasaan tidak percaya, sedih, menolak, kecewa. Tidak mudah bagi orang tua yang anaknya menyandang autisme untuk mengalami fase ini, sebelum pada akhirnya sampai pada tahap penerimaan. Orangtua terkadang merenung dan tidak mengetahui tindakan tepat apa yang harus diperbuat. Tidak sedikit orangtua yang kemudian memilih menutupi keadaan anaknya kepada teman, tetangga bahkan keluarga dekat sekalipun, kecuali pada dokter yang menangani anaknya tersebut (Puspita dalam Rachmayanti, 2007). Banyak masyarakat Indonesia yang belum mengenal secara jelas tentang autisme (Priyatna, 2015). Di kalangan masyarakat juga masih ada pemahaman bahwa anak-anak autisme dapat menularkan penyakitnya (Harwono, 2012). Autisme masih menjadi mimpi buruk bagi sebagian besar orang tua. Beberapa orang tua langsung merasa stress saat mendengar anaknya didiagnosis autisme (Harwono, 2012).

Florida Institute of Technology melakukan survei pada bulan November tahun 2012, mencatat bahwa sebanyak dua per tiga orang tua muda mengkhawatirkan anaknya dapat terdiagnosis autisme (NN dalam Parenting Indonesia, 2012).Setiaporangtua pastinya menginginkan anaknya dapat bertumbuh dengan sehat dan berkembang secara normal, seperti anak pada umumnya.Namun, pada kenyataannya, tidak segala sesuatu dapat berjalan sesuai yang diinginkan, Setiap anak tentunya akan melalui proses pertumbuhan dan perkembangan yang berbeda-beda.Inilah yang terjadi pada setiap orangtua yang memiliki anak dengan autisme.

Autisme merupakangangguan yang heterogen(Veague, 2010). Heterogen yang dimaksudkan di sini berarti setiap orang yang memiliki autisme dapat terlihat dan bertingkah laku sangat berbeda dari yang lainnya. Autisme merupakan gangguan yang mempengaruhi perkembangan otak (Freedman, 2008). Freedman (2008) mengatakan bahwa biasanya gejala autisme pada anak mulai muncul sejak kecil dan pada umumnya didiagnosa saat anak berusia tiga tahun, meskipun dapat juga didiagnosa sejak usia 18 bulan. Autisme menyebabkan gangguan dalam seluruh aspek perkembangan seseorang. Anak dengan Autisme memiliki masalah dalam berbicara dan dalam memahami sesuatu, dan biasanya mereka mengalami kesulitan untuk berinteraksi dengan orang lain serta lingkungan. Mereka lebih suka bermain dengan dunianya sendiri. Selain itu, anak dengan autisme biasanya sangat sensitif. Mereka dapat merasakan sesuatu dengan indera mereka lebih tajam dari orang normal. Hal ini menyebabkan mereka sangat peka terhadap cahaya terang, suara yang keras, bau, rasa, ataupun sentuhan, sehingga mereka cenderung menjauhi orang lain (Freedman, 2008).

Mangunsong (2009) menyatakan bahwa ada tiga gejala utama individu dengan Autistic Spectrum Disorder (ASD), yaitu: (1) Gangguan Interaksi Sosial (2) Gangguan Komunikasi, (3) Gangguan Perilaku. Dampakdampak yang dialami anak dengan autis (Mangunsong, 2009) seperti gangguan kognisi, gangguan persepsi sensori, gangguan perilaku motorik, gangguan tidur dan makan, 
gangguan afeksi dan mood, tingkah laku agresif dan membahayakan.

Seringkali orangtua tidak memahami kondisi anak dengan autisme, sehingga yang terjadi adalah muncul kebingungan yang menyebabkan konflik dalam diri orangtua itu sendiri (Faridah dalam Novia \& Kurniawan, 2007). Faridah (dalam Novia \& Kurniawan, 2007) mengatakan bahwa orangtua harus dapat berjuang bagi anaknya, terlebih lagi untuk anak dengan autisme. Karena anak dengan autisme tetaplah seorang anak yang membutuhkan dukungan, kasih sayang, perhatian, dan cinta dari orangtuanya. Oleh karena itu, orangtua harus bisa menerima setiap kekurangan yang dialami oleh anaknya serta bangkit dari perasaan kaget, sedih, khawatir, malu dan takut yang biasanya dirasakan para orangtua saat pertama kali mengetahui bahwa anaknya terdiagnosa autisme (Safaria dalam Novia \& Kurniawan, 2007).

$\begin{array}{ccc}\text { Johada } & \text { (dalam } & \text { Rizkiana \& } \\ \text { Retnaningsih, } & \text { 2008) } & \text { menyatakan }\end{array}$ bahwapenerimaan diri berarti seorang individu telah belajar untuk hidup dengan dirinya sendiri, dalam arti individu dapat menerima kelebihan maupun kekurangan yang ada dalam dirinya. Hal inilah yang dibutuhkan oleh para orangtua yang memiliki anak dengan autisme. Dimana mereka harus bisa menerima diri mereka sendiri bahwa mereka bukan sebagai orangtua yang gagal, dan mereka dapat menerima setiap kekurangan dan keunikan yang dimiliki oleh anak-anak mereka. Penerimaan bukan berarti menoleransi sesuatu yang membuat kita sengsara, tetapi penerimaan berarti menyadari kekuatan yang kita miliki dalam diri kita untuk menjadi bahagia, kuat dan sukses sekarang. Karena penerimaan merupakan langkah pertama untuk bisa menciptakan perubahan dalam hidup seseorang (White, 2011).

Hurlock (dalam Ardilla \& Herdiana, 2013) mengemukakan faktor-faktor yang berperan dalam proses penerimaan diri tersebut, yaitu: (1) Pemahaman tentang diri sendiri, (2) Harapan realistik, (3) Tidak adanya hambatan di lingkungan, (4) Sikap-sikap anggota masyarakat yang menyenangkan, (5) Tidak adanya gangguan emosional yang berat, (6) Pengaruh keberhasilan yang dialami, (7) Identifikasi dengan orang yang memiliki penyesuaian diri yang baik, (8) Adanya perspektif diri yang luas, (9) Pola asuh di masa kecil yang baik, (10) Konsep diri yang stabil. White (2012) juga menjelaskan beberapa aspek yang dapat mempengaruhi seseorang dalam mencapai penerimaan diri, antara lain adalah Story(pengalaman masa lalu), Pattern(Perilaku pemecahan masalah), Limiting Belief(Kepercayaan), Emotion(Reaksi emosi).

Berdasarkan pernyataan dariorangtuayang memiliki anak dengan autisme, dapat disimpulkan satu hal bahwa semakin lama orangtua menerima kondisi anaknya, maka akan lebih lambat bagi sang anak untuk mendapatkan intervensi mengenai gangguannya.

Penelitian sebelumnya yang dilakukan oleh Sri Rachmayanti dan Anita Zulkaida (2008) memaparkan bahwa orang tua yang memiliki anak dengan autisme sebaiknya melakukan deteksi dan intervensi sejak dini, sehingga dapat mengetahui dengan cepat mengenai cara penangan yang tepat. Bedasarkan wawancara yang telah dilakukan pada lima orang tua yang memiliki anak autisme serta bedasarkan penelitian sebelumnya, Peneliti menarik kesimpulan bahwa sangatlah penting bagi seorang orangtua yang memiliki anak dengan autisme untuk yang terutama menerima diri mereka sendiri dan menerima keadaan anaknya sehingga orangtua dapat mengasuh dan merawat anaknya dengan baik meskipun dihadapkan pada situasi-situasi yang unik atau berbeda dalam prosesnya. Sehingga, peneliti tertarik untuk melihat faktor apa yang dapat mempengaruhi penerimaan diri orangtua yang memiliki anak dengan autisme.Penelitian ini mempunyai tujuan untuk mengetahui gambaran faktor-faktor yang dapat mempengaruhi penerimaan diri pada orangtua yang memiliki anak autisme.

Menurut Johada (dalam Rizkiana \& Retnaningsih, 2008) penerimaan diri mengandung pengertian bahwa individu telah belajar untuk hidup dengan dirinya sendiri, yang berarti individu dapat menerima kelebihan maupun kekurangan yang ditemukan dalam dirinya. Hampir serupa dengan pernyataan Ryff (dalam Meilinda, 2013), dimana dinyatakan bahwa penerimaan diri adalah keadaan dimana seorang individu memiliki penilaian positif terhadap dirinya, menerima serta mengakui segala dirinya tanpa merasa malu atau merasa bersalah terhadap 
kodrat dirinya. Jersild (dalam Pancawati, 2013) juga menyatakan bahwa penerimaan diri merupakan seseorang yang menerima dirinya dan menghormati dirinya serta hidup nyaman dengan keadaan dirinya, mampu mengenali, memiliki harapan, keinginan, rasa takut serta permusuhan-permusuhannya dan menerima kecenderungan-kecenderungan emosinya bukan dalam arti puas dengan diri sendiri tetapi memiliki kebebasan untuk menyadari sifat dari perasaan-perasaan.

Berdasarkan beberapa pengertian di atas, dapat disimpulkan bahwa penerimaan diri berarti seseorang yang telah dapat memahami kelebihan dan kekurangan yang ada dalam dirinya dan dapat memberikan pandangan yang positif terhadap dirinya sendiri.

Hurlock (dalam Ardilla\&Herdiana, 2013) mengemukakan faktor-faktor yang berperan dalam proses penerimaan diri tersebut, yaitu:

1. Pemahaman tentang Diri Sendiri

Pemahaman ini timbul dari kesempatan seseorang untuk mengenali kemampuan dan ketidakmampuannya. Tidak hanya itu, seorang individu yang memahami dirinya sendiri juga mencoba menunjukan kemampuannya. Semakin individu memahami dirinya, maka semakin besar penerimaan individu terhadap dirinya.

2. Harapan Realistik

Harapan yang realistik atau nyata atau dapat diwujudkan timbul jika individu menentukan sendiri harapannya dimana harapan tersebut disesuaikan dengan pemahaman kemampuannya, dan bukan diarahkan oleh orang lain. Dengan harapan realistik, akan semakin besar kesempatan tercapainya harapan tersebut sehingga menimbulkan kepuasan diri.

3. Tidak Adanya Hambatan di Lingkungan Harapan individu akan sulit tercapai bila lingkungan di sekitarnya tidak memberikan kesempatan atau bahkan menghalangi (walaupun harapan individu sudah realistik).

4. Sikap-sikap Anggota Masyarakat yang Menyenangkan

Tidak adanya prasangka serta adanya penghargaan terhadap kemampuan sosial orang lain dan kesediaan individu mengikuti kebiasaan lingkungan.

5. Tidak Adanya Gangguan Emosional yang Berat
Tidak adanya gangguan emosional yang berat akan membuat individu dapat bekerja sebaik mungkin dan merasa bahagia.

6. Pengaruh Keberhasilan yang Dialami

Keberhasilan yang dialami dapat menimbulkan penerimaan diri (yang positif). Sebaliknya, kegagalan yang dialami mengakibatkan adanya penolakan diri.

7. Identifikasi dengan Orang yang Memiliki Penyesuaian Diri yang Baik

Individu yang mengidentifikasi diri dengan orang yang dapat menyesuaikan dirinya dengan baik (well adjusted), dapat membangun sikap-sikap yang positif terhadap diri sendiri dan bertingkah laku dengan baik. Hal ini dapat menimbulkan penerimaan diri dan penilaian diri yang baik.

8. Adanya Perspektif Diri yang Luas

Perspektif diri yang luas berarti memperhatikan pandangan orang lain tentang diri. Perspektif diri yang luas ini diperoleh melalui pengalaman dan belajar.

9. Pola Asuh di Masa Kecil yang Baik

Anak yang diasuh secara demokratis akan cenderung berkembang sebagai orang yang dapat menghargai dirinya sendiri.

10. Konsep Diri yang Stabil Individu yang tidak memiliki konsep diri yang stabil (misalnya, kadang menyukai diri dan kadang tidak menyukai diri), akan sulit menunjukan pada orang lain siapa ia sebenarnya, sebab ia sendiri ambivalen terhadap dirinya.

Individual with Disabilities Education Act (IDEA) mendefinisikan autisme sebagai gangguan perkembangan yang mempengaruhi komunikasi verbal dan nonverbal serta interaksi sosial (Mangunsong, 2009). Biasanya, gejalanya mulai tampak sebelum anak berusia 3 tahun. Bahkan pada autisme infantile, gejalanya sudah ada sejak lahir. Anak penyandang autis mempunyai masalah gangguan dalam bidang komunikasi, interaksi sosial, gangguan sensoris, pola bermain, perilaku dan emosi (Suyanti dalam Rachmayanti \& Zulkaida, 2007).

\section{METODE PENELITIAN}

Dalam penelitian ini, peneliti menggunakan metode penelitian kualitatif dengan jenis studi kasus. Penelitian kualitatif 
adalah penelitian yang mendasarkan diri pada kekuatan narasi, studi yang dilakukan dalam situasi alamiah, menggunakan analisis induktif, kontak personal langsung dimana peneliti langsung turun kelapangan, perspektif holistik, perspektif dinamis, orientasi pada kasus yang unik, bersandar pada netralitas empatis, ada fleksibilitas desain, sirkuler, dan peneliti merupakan instrument kunci (Poerwandari, 2011). Karakteristik subjek yang dilibatkan dalam penelitian ini adalah orang tua yang memiliki anak dengan autisme.Jumlah subjek dalam penelitian ini adalah 5 orang.

Teknik sampling yang digunakan untuk menentukan sampel dalam penelitian ini adalah purposivesampling. purposivesampling adalah pertimbangan atau keputusan dari peneliti untuk menentukan siapa yang dapat memberikan informasi teknik untuk mendapatkan objektivitas dari penelitian tersebut, peneliti akan mengarah kepada sumber yang ia anggap memiliki informasi yang diperlukan dan bersedia memberikan informasi tersebut (Kumar, 2011).

\section{HASIL DAN PEMBAHASAN}

\begin{tabular}{cccccc}
\hline Subjek & $\mathrm{K}$ & $\mathrm{T}$ & $\mathrm{D}$ & $\mathrm{H}$ & $\mathrm{N}$ \\
\hline Usia & 49 & 51 & 46 & 58 & 37 \\
Jenis & $\mathrm{P}$ & $\mathrm{L}$ & $\mathrm{L}$ & $\mathrm{P}$ & $\mathrm{P}$ \\
$\begin{array}{c}\text { Kelamin } \\
\text { Usia anak } \\
\text { saat ini }\end{array}$ & 14 & 10 & 10 & $6 \mathrm{Thn}$ & $14 \mathrm{Thn}$ \\
$\begin{array}{c}\text { Usia anak } \\
\text { saat }\end{array}$ & $2 \mathrm{Thn}$ & $8 \mathrm{Thn}$ & $\mathrm{Thn}$ & $7 \mathrm{Bln}$ & \\
$\begin{array}{c}\text { terdiagnos } \\
\text { a }\end{array}$ & & & & $2 \mathrm{Bln}$ & \\
$\begin{array}{c}\text { Faktor } \\
\text { yang }\end{array}$ & 8 & 10 & 6 & 7 & 8 \\
$\begin{array}{c}\text { mempeng } \\
\text { aruhi }\end{array}$ & faktor & faktor & faktor & faktor & faktor \\
\hline
\end{tabular}

Bedasarkan hasil penelitian, dapat disimpulkan bahwa dari kelima subjek memiliki faktor-faktor yang berbeda dalam proses penerimaan diri mereka. Faktor proses penerimaan yang dimiliki oleh $\mathrm{K}$ adalah Pemahaman tentang diri sendiri, Harapan realistik, Tidak adanya hambatan di lingkungan, Sikap-sikap anggota masyarakat yang menyenangkan, Tidak adanya gangguan emosional yang berat, identifikasi dengan orang yang memiliki penyesuaian diri, Adanya perspektif diri yang luas, Konsep diri yang stabil.

Faktor proses penerimaan yang dimiliki oleh $\mathrm{T}$ adalah Pemahaman tentang diri sendiri, Harapan realistik, Tidak adanya hambatan di lingkungan, Sikap-sikap anggota masyarakat yang menyenangkan, Tidak adanya gangguan emosional yang berat, pengaruh keberhasilan, identifikasi dengan orang yang memiliki penyesuaian diri, Adanya perspektif diri yang luas, Pola asuh di masa kecil yang baik, Konsep diri yang stabil.

Faktor proses penerimaan yang dimiliki oleh D adalah Pemahaman tentang diri sendiri, Harapan realistik, Sikap-sikap anggota masyarakat yang menyenangkan, Tidak adanya gangguan emosional yang berat, identifikasi dengan orang yang memiliki penyesuaian diri, Adanya perspektif diri yang luas, Pola asuh di masa kecil yang baik, Konsep diri yang stabil.

Faktor proses penerimaan yang dimiliki oleh $\mathrm{H}$ adalah Pemahaman tentang diri sendiri, Harapan realistik, Tidak adanya hambatan di lingkungan, Sikap-sikap anggota masyarakat yang menyenangkan, Tidak adanya gangguan emosional yang berat, identifikasi dengan orang yang memiliki penyesuaian diri, Adanya perspektif diri yang luas, Konsep diri yang stabil.

Faktor proses penerimaan yang dimiliki oleh $\mathrm{N}$ adalah Pemahaman tentang diri sendiri, Harapan realistik, Tidak adanya hambatan di lingkungan, Sikap-sikap anggota masyarakat yang menyenangkan, Tidak adanya gangguan emosional yang berat, identifikasi dengan orang yang memiliki penyesuaian diri, Adanya perspektif diri yang luas, Konsep diri yang stabil.

Faktor yang tidak dimiliki oleh subjek $\mathrm{K}$ adalah Pola asuh di masa kecil yang baik dan Pengaruh keberhasilan yang dialami. Faktor yang tidak dimiliki oleh D adalah hambatan di lingkungan, Pengaruh keberhasilan yang dialami serta Konsep diri yang stabil. Faktor yang tidak dimiliki oleh $\mathrm{H}$ adalah Pengaruh keberhasilan yang dialami, pola asuh dimasa kecil yang baik serta konspe diri yang stabil. Faktor yang tidak dimiliki oleh $\mathrm{N}$ adalah Pengaruh keberhasilan yang 
dialami dan pola asuh dimasa kecil yang baik. Sedangkan untuk subjek $\mathrm{T}$ sudah memenuhi kesepuluh faktor yang ada.

\section{DISKUSI}

Menurut Hurlock (1974) dampak penerimaan diri terbagi dalam dua katergori, yang pertama dalam penyesuaian diri orang yang memiliki penerimaan diri, mampu mengenali kelebihan dan kekurangannya. Ia biasanya memiliki keyakinan diri (self confidence) dan harga diri (self esteem). Selain itu mereka juga lebih dapat menerima kritik demi perkembangan dirinya.

Penerimaan diri yang disertai dengan adanya rasa aman untuk mengembangkan diri, memungkinkan seseorang untuk menilai dirinya secara lebih realistis sehingga dapat menggunakan potensinya secara efektif. Dengan penilaian yang realistis terhadap diri, seseorang akan dapat bersikap jujur dan tidak berpura-pura. Sehingga ia merasa puas dengan menjadi dirinya sendiri tanpa adanya keinginan untuk menjadi orang lain.

Subjek $\mathrm{K}, \mathrm{T}, \mathrm{D}, \mathrm{H}$, dan $\mathrm{N}$ memiliki penyesuaian diri yang baik, dimana mereka sudah mampu mengenali diri mereka serta mereka sudah mampu memahami hal-hal apa saja yang menjadi kelebihan maupun kekurangan anaknya. Kelima subjek juga sudah bisa menerima keberadaan anaknya.

Dampak penerimaan diri yang kedua adalah dalam penyesuaian sosial, Penerimaan diri biasanya disertai dengan adanya penerimaan pada orang lain. Orang yang memiliki penerimaan diri akan merasa aman untuk menerima orang lain, memberikan perhatiannya pada orang lain, serta menaruh minat terhadap orang lain, seperti menunjukan rasa empati dan simpati. Sehingga orang yang memiliki penerimaan diri dapat melakukan penyesuaian sosial yang lebih baik dibandingkan dengan orang yang merasa rendah diri dimana mereka cenderung berorientasi pada dirinya sendiri (self oriented). Ia dapat mengatasi keadaan emosionalnya tanpa mengganggu orang lain, serta toleran dan memiliki dorongan untuk membantu orang lain. Kelima subjek K, T, D, $\mathrm{H}$, dan $\mathrm{N}$ mampu menerima serta memberikan perhatian kepada orang lain seperti tetangga atau keluarga. e- ISSN: 2581-0871

Sarason dan Sarason (dalam Smet, 1994) mengemukakan bahwa dukungan sosial adalah dukungan yang didapat dari keakraban sosial (teman, keluarga, anak ataupun orang lain) berupa pemberian informasi, nasehat verbal atau non verbal, bantuan nyata atau tidak nyata. Tindakan yang bermanfaat sosial dan efek perilaku bagi penerima yang akan melindungi diri dari perilaku yang negatif. $\mathrm{K}$ mendapat dukungan dari keluarga, dukungan yang diberikan berupa informasi mengenai tempat terapi serta informasi mengenai makanan apa saja yang tidak boleh dikonsumsi untuk anak autisme. Selain itu K mendapat dukungan dari lingkungan, dukungan yang diberikan berupa informasi mengenai bagaimana cara menangani anak autisme serta informasi mengenai tempat terapi.

$\mathrm{T}$ mendapat dukungan dari keluarga, dukungan yang diberikan berupa materi untuk biaya terapi serta memberikan informasi mengenai tempat terapi yang baik. Selain itu T mendapat dukungan dari lingkungan, dukungan yang diberikan lebih ke saran untuk alternatif dibandingkan saran untuk ke dokter.

D mendapat dukungan dari keluarga, dukungan yang diberikan berupa bantuan dalam mencari rumah sakit yang tepat untuk melakukan terapi serta mencarikan sekolah yang dapat menggembangkan kemampuan anaknya. Selain itu D mendapat dukungan dari lingkungan, dukungan yang diberikan berupa kata-kata yang memotivasi D serta memberikan masukan mengenai tempat terapi yang bagus untuk anak autisme.

$\mathrm{H}$ mendapat dukungan dari keluarga, dukungan yang diberikan berupa bantuan informasi dalam mencari sekolah serta tempat terapi. Selain itu $\mathrm{H}$ mendapat dukungan dari lingkungan, dukungan yang diberikan berupa kata-kata yang memotivasi $\mathrm{H}$.

$\mathrm{N}$ mendapat dukungan dari keluarga, dukungan yang diberikan berupa materi, memberikan informasi mengenai sekolah atau terapi, serta memberikan motivasi untuk $\mathrm{N}$. Selain itu $\mathrm{N}$ mendapat dukungan dari lingkungan, dukungan yang diberikan berupa informasi mengenai tempat sekolah serta memberikan $\mathrm{N}$ kata-kata yang memotivasi.

Hurlock (dalam Ardilla \& Herdiana, 2013) mengemukakan faktor-faktor yang 
berperan dalam proses penerimaan diri tersebut. Pertama Pemahaman tentang diri sendiri, dimana pemahaman ini timbul dari kesempatan seseorang untuk mengenali kemampuan dan ketidakmampuannya. Tidak hanya itu, seorang individu yang memahami dirinya sendiri juga mencoba menunjukan kemampuannya. Semakin individu memahami dirinya, maka semakin besar penerimaan individu terhadap dirinya. Dalam hal ini kelima subjek $\mathrm{K}, \mathrm{T}, \mathrm{D}, \mathrm{H}$, dan $\mathrm{N}$ memiliki pemahaman diri sendiri yang baik, mereka memahami perasaan mereka ketika mengetahui hasil diagnosa.

Subjek K sebelum mengetahui anaknya terdiagnosa autisme ia memiliki perasaan sedih, serta bertanya-tanya mengapa dikaruniai anak seperti itu, tetapi hal itu tidak membuat $\mathrm{K}$ berputus asa ia tetap berusaha melakukan yang terbaik untuk anaknya. $\mathrm{K}$ mencoba mensyukuri apa yang telah diberikan oleh Tuhan, sehingga $\mathrm{K}$ sudah mulai bisa menerima keadaan anaknya. $\mathrm{T}$ mengatakan bahwa ia merasa sedih serta kecewa ketika mengetahui anak tersebut terdiagnosa autisme.Subjek D merasa sedih dan kecewa, tetapi hal ini tidak membuat $\mathrm{D}$ berputus asa untuk membuat anaknya jadi lebih baik lagi.Subjek $\mathrm{H}$ merasa sedih, kaget, serta terkejut ketika mengetahui hasil diagnosa tersebut, tetapi ia mengatakan bahwa bagaimanapun keadaan anaknya ia adalah tetap ananknya, awalanya $\mathrm{H}$ sempat merasa malu ketika membawa anaknya untuk kesekolah ataupun ke rumah saudara, untuk sekarang $\mathrm{H}$ sudah tidak merasa malu ketika membawa jalan anaknya.

Subjek N merasa sedih ketika mengetahui anaknya terdiagnosa autisme, karena menurutnya anak yang pertama yang dinanti-nantikannya tidak sesuai dengan harapan. $\mathrm{N}$ tidak pernah merasa malu memiliki anak autisme, $\mathrm{N}$ sempat memiliki pemikiran mengapa ia diberikan anak autisme tetapi dia tetap berpikir positif dan ia mengatakan mungkin Tuhan memberikan anak autisme untuk mengajarkan $\mathrm{N}$ mengenai kesabaran. Hal ini tidak membuat $\mathrm{T}$ patah semangat, $\mathrm{T}$ tetap berusaha yang terbaik untuk anaknya. Sampai pada akhirnya $\mathrm{T}$ belajar untuk mengikhlaskan keadaan anaknya.

Kedua, Harapan realistik, harapan yang realistik atau nyata atau dapat diwujudkan timbul jika individu menentukan sendiri harapannya dimana harapan tersebut disesuaikan dengan pemahaman kemampuannya, dan bukan diarahkan oleh orang lain. Dengan Harapan realistik, akan semakin besar kesempatan tercapainya harapan tersebut sehingga menimbulkan kepuasan diri. Kelima subjek K, T, D, H, dan $\mathrm{N}$ mampu menjelaskan apa yang menjadi harapannya sebelum memiliki anak autisme dan apa yang menjadi harapannya setelah mengetahui bahwa anaknya terdiagnosa autisme. Harapan subjek K sebelum mengetahui anaknya terdiagnosa autisme bahwa anak tersebut dapat menjadi anak yang sholeh, pintar, mandiri, dan dapat membanggakan orang tua, setelah menyadari anak tersebut terdiagnosa autisme, harapan subjek K kepadanya agar ia bisa mandiri dalam kehidupan sehari-harinya. Sebelum mengetahui anaknya terdiagnosa autisme, harapan subjek $\mathrm{T}$ anak tersebut dapat menjadi anak yang mandiri serta memiliki prestasi yang baik dalam bidang akademik. Setelah menyadari anak tersebut terdiagnosa autisme, harapan subjek $\mathrm{T}$ kepadanya agar ia bisa mandiri tanpa bantuan dari orang lain. Sebelum mengetahui anaknya terdiagnosa autisme, harapan subjek D anak tersebut dapat menempuh pendidikan $\mathrm{S} 1$, cerdas dalam bidang pendidikan, serta dapat hidup mandiri. Setelah menyadari anak tersebut terdiagnosa autisme, harapan subjek D kepadanya agar ia bisa sekolah dengan baik serta mandiri dan tidak bergantung dengan orang lain.

Sebelum mengetahui anaknya terdiagnosa autisme, harapan subjek $\mathrm{H}$ anak tersebut dapat menjadi seorang laki-laki pemberani yang bisa mengekspresikan kemampuan yang dimiliki. Setelah menyadari anak tersebut terdiagnosa autisme, harapan subjek $\mathrm{H}$ kepadanya agar ia bisa mandiri dalam hal makan sendiri maupun menggunakan pakaian sendiri dan tidak bergantung hidup dengan orang lain.Sebelum mengetahui anaknya terdiagnosa autisme, harapan subjek $\mathrm{N}$ anak tersebut dapat menjadi anak yang pintar, anak yang rajin, anak yang bisa membantu orang tua. Setelah menyadari anak tersebut terdiagnosa autisme, harapan subjek $\mathrm{N}$ kepadanya agar ia bisa mandiri dan tidak malas dalam hal sekolah maupun dalam hal mandi

Ketiga, Tidak adanya hambatan di lingkungan, Harapan individu akan sulit tercapai bila lingkungan di sekitarnya tidak 
memberikan kesempatan atau bahkan menghalangi (walaupun harapan individu sudah realistik). Dari kelima subjek hanya keempat subjek yaitu subjek $\mathrm{K}, \mathrm{T}, \mathrm{H}$, dan $\mathrm{N}$ yang mendapat dukungan dari lingkungan sekitar, dukungan yang diberikan lingkungan sekitar berupa informasi mengenai tempat sekolah maupun tempat terapi, serta kata-kata yang dapat memotivasi. Sedangkan D tidak mendapat dukungan dari lingkungan sekitar, D mengatakan bahwa anak-anak sekitar rumahnya tidak mau bermain dengan anaknya.

Keempat, Sikap-sikap anggota masyarakat yang menyenangkan, tidak adanya prasangka serta adanya penghargaan terhadap kemampuan sosial orang lain dan kesediaan individu mengikuti kebiasaan lingkungan. Kelima subjek $\mathrm{K}, \mathrm{T}, \mathrm{D}, \mathrm{H}$, dan $\mathrm{N}$ mendapat dukungan baik dari pihak keluarga maupun dari lingkungan sekitarnya. Dukungan yang diberikan oleh keluarga baik informasi seputar tempat sekolah dan tempat terapi serta dukungan secara materi.

Kelima, Tidak adanya gangguan emosional yang berat, Tidak adanya gangguan emosional yang berat akan membuat individu dapat bekerja sebaik mungkin dan merasa bahagia. Kelima subjek $\mathrm{K}, \mathrm{T}, \mathrm{D}, \mathrm{H}$, dan $\mathrm{N}$ tidak memiliki gangguan emosional yang berat, mereka hanya terkadang kesal dengan tingkah anak mereka.

Subjek K pernah merasa emosi kepada anaknya ketika anak tersebut masih membuang air kecil di celana, hal ini membuat ia merasa kesal hingga subjek $\mathrm{K}$ pernah memukuli anaknya. Lingkungan sekitar subjek $\mathrm{K}$ juga pernah membuat ia merasa emosi. Hal yang membuat dia emosi dikarenakan katakata yang tidak baik yang ia terima dari tetangganya.Subjek $\mathrm{T}$ pernah merasa kesal saat anaknya sulit untuk fokus dan tidak bisa diam. Respon subjek T ketika mendapat situasi tersebut subjek $\mathrm{T}$ membentak serta memukuli anaknya. Lingkungan sekitar subjek $\mathrm{T}$ juga pernah membuat ia merasa sangat kecewa. Hal yang membuat dia emosi dikarenakan tetangganya memukuli anak tersebut. Subjek D juga pernah merasa marah kepada anaknya ketika ia menyuruh anaknya untuk melakukan sesuatu. tetapi anak tersebut tidak bisa langsung merespon, sehingga membuat ia harus memberitahu anak tersebut berulangulang. Hal yang dilakukan subjek D ketika anak tersebut membuat ia merasa emosi adalah subjek D memukuli kakinya. Subjek D juga pernah dibuat emosi oleh tetangga-tetangga sekitar rumahnya, ia juga mengatakan bahwa bentuk emosional yang ia terima dari lingkungan bisa berupa fisik maupun verbal.

Subjek $\mathrm{H}$ pernah merasa kesal kepada anaknya ketika anak tersebut melakukan hal yang salah. Respon subjek $\mathrm{H}$ ketika mendapat situasi tersebut subjek $\mathrm{H}$ membentak serta memukuli kaki anaknya. Lingkungan sekitar subjek $\mathrm{H}$ juga pernah membuat ia merasa sangat emosi. Hal yang membuat dia emosi dikarenakan perlakuan yang tidak baik dari orang lain kepada anaknya. Subjek N pernah merasa kesal kepada anaknya ketika anak tersebut membanting-banting handphone karena hal ini membuat subjek $\mathrm{N}$ harus membelikannya lagi. Selain itu hal yang membuat subjek $\mathrm{N}$ kesal adalah ketika anak tersebut disuruh untuk makan, tetapi anak tersebut tidak mau makan. Respon subjek $\mathrm{N}$ ketika mendapat situasi tersebut subjek $\mathrm{N}$ mengomeli dan meninggalkan anak tersebut. Lingkungan sekitar subjek $\mathrm{N}$ juga pernah membuat ia merasa kesal. Hal yang membuat dia emosi dikarenakan lingkungan sekitar rumahnya terkadang sering membicarakannya.

Keenam, Pengaruh keberhasilan yang dialami, Keberhasilan yang dialami dapat menimbulkan penerimaan diri (yang positif).Sebaliknya, kegagalan yang dialami mengakibatkan adanya penolakan diri. Subjek $\mathrm{D}, \mathrm{K}, \mathrm{H}, \mathrm{N}$ menggangap bahwa diri mereka belum berhasil dalam mendidik anak mereka, karena anak tersebut belum bisa mandiri dalam kehidupan sehari-hari. Sedangkan subjek $\mathrm{T}$ menggatakan bahwa ia sudah berhasil dalam mendidik anak tersebut.

Subjek K menganggap bahwa dirinya belum berhasil dalam mendidik anaknya, karena menurutnya masih banyak yang harus diperbaiki lagi. subjek $\mathrm{K}$ mengatakan bahwa anak tersebut juga belum bisa mandiri, seperti makan dan mandi belum bisa dilakukan sendiri. Subjek T menganggap bahwa dirinya sudah berhasil dalam mendidik anaknya. Keberhasilan yang dicapai berupa kemandirian, anak tersebut sudah bisa mandiri seperti makan sendiri, mengambil minum sendiri, serta menggunakan baju sendiri. Subjek D menganggap bahwa dirinya belum berhasil dalam mendidik anaknya, dikarenakan menurut subjek D anak tersebut masih belum terlalu lancar dalam berbicara. Subjek $\mathrm{H}$ 
menganggap bahwa dirinya belum berhasil dalam mendidik anaknya, dikarenakan menurut subjek $\mathrm{H}$ anaknya belum bisa mandiri dalam kesehariannya. Subjek N menganggap bahwa dirinya belum berhasil dalam mendidik anaknya, dikarenakan menurut subjek $\mathrm{N}$ anaknya masih sulit untuk sekolah, untuk tidak mengompol, dan subjek $\mathrm{N}$ belum berhasil untuk membuat anak tersebut untuk tidak mudah emosi.

Ketujuh, Identifikasi dengan orang yang memiliki penyesuaian diri yang baik, Individu yang mengidentifikasi diri dengan orang yang dapat menyesuaikan dirinya dengan baik (well adjusted), dapat membangun sikap-sikap yang positif terhadap diri sendiri dan bertingkah laku dengan baik. Hal ini dapat menimbulkan penerimaan diri dan penilaian diri yang baik. Kelima subjek $\mathrm{K}, \mathrm{T}, \mathrm{D}, \mathrm{H}$, dan $\mathrm{N}$ memiliki panutan tersendiri. $\mathrm{K}$ memiliki seorang panutan yaitu tokoh dalam sebuah buku yang berjudul bapak Adit, karena tokoh ini $\mathrm{K}$ banyak belajar mengenai anak autisme. $\mathrm{T}$ memiliki sosok panutan yaitu orang tua dari Ilham (anak autisme) karena T mengginginkan anak tersebut dapat seperti Ilham yang memiliki memory yang cukup baik. D tidak memiliki panutan tersendiri. $\mathrm{H}$ memiliki panutan yaitu seorang berkebutuhan khusus yang dapat menjadi seorang penulis. $\mathrm{T}$ memiliki panutan yaitu ibu Teti karena dari ibu Teti ia banyak belajar cara menggali potensi yang dimiliki anaknya.

Kedelapan, Adanya Perspektif Diri yang Luas, Perspektif diri yang luas berarti memperhatikan pandangan orang lain tentang diri. Perspektif diri yang luas ini diperoleh melalui pengalaman dan belajar. Pandangan orang lain terhadap kelima subjek K, T, D, H, dan Nadalah pandangan yang positif. Orang lain memandang $\mathrm{K}$ sebagai orang yang sabar dan rajin dalam mengurus dan mendidik anaknya. Orang lain memandang $\mathrm{T}$ adalah orang yang rajin, setia, serta sabar dalam mendidik anaknya. Orang lain memandang D adalah orang yang tegar serta rajin dalam mendidik anak. Orang lain memandang $\mathrm{H}$ orang yang tegar sehingga dipercayakan Tuhan untuk mengurus anak berkebutuhan khusus. Serta padangan orang terhadap N adalah orang yang rajin dalam mendidik anaknya.

Kesembilan, Pola asuh di masa kecil yang baik, Anak yang diasuh secara demokratis akan cenderung berkembang sebagai orang yang dapat menghargai dirinya sendiri. Pola asuh yang diterima oleh subjek D dan $\mathrm{T}$ pada saat kecil adalah pola asuh demokratis. Menurut Barnadib (dalam Aisyah, 2010) keluarga yang diasuh dengan pola asuh demokratis, yang berarti hubungan anak dengan orang tuanya harmonis, mempunyai sifat terbuka dan bersedia mendengarkan pendapat orang lain. Sehingga mampu menyesuaikan diri dengan lingkungannya. Dalam hal ini $\mathrm{D}$ dan $\mathrm{T}$ mengatakan bahwa mereka memiliki sifat yang terbuka dengan orang lain, sehingga mereka lebih bisa menerima saran dari orang lain dan mampu menyesuaikan diri dengan lingkungan sekitar. Sedangkan pola asuh yang diterima subjek K, $\mathrm{H}$, dan $\mathrm{N}$ pada masa kecil adalah pola asuh otoriter. Menurut Stweart dan Koch (dalam Aisyah, 2010) orangtua yang otoriter cenderung memberi hukuman terutama hukuman secara fisik, hal ini terlihat dimana subjek $\mathrm{K}, \mathrm{H}$, dan $\mathrm{N}$ mengatakan bahwa ketika ada ada hal dari anak yang membuat mereka merasa emosi, biasanya hal yang mereka lakukan adalah dengan cara memarahi serta memukul anak tersebut. Selain itu dikatakan bahwa pola asuh otoriter yang berarti orang tua tidak mendorong serta memberikan kesempatan kepada anak untuk mandiri dan jarang memberi pujian. Subjek K, H, dan N menaggap bahwa anaknya belum berhasil dalam hal kemandirian untuk kehidupan sehari - hari, misalnya makan sendiri, mandi sendiri, serta menggunakan pakaian sendiri.

Kesepuluh, Konsep diri yang stabil, Individu yang tidak memiliki Konsep diri yang stabil (misalnya, kadang menyukai diri dan kadang tidak menyukai diri), akan sulit menunjukan pada orang lain siapa ia sebenarnya, sebab ia sendiri ambivalen terhadap dirinya. Dalam memutuskan sebuah pilihan subjek $\mathrm{K}$ tetap pada pendapat sendiri tanpa memperdulikan pendapat yang disampaikan oleh orang lain. Selain itu, pada saat mendidik anak subjek $\mathrm{K}$ lebih pada ke pendapat sendiri, karena menurut subjek $\mathrm{K}$ ia yang lebih mengetahui apa yang menjadi kekurangan anaknya. Subjek K mengatakan bahwa ia orang yang konsisten. Pada saat menentukan sebuah pilihan, subjek $\mathrm{T}$ lebih memilih pendapat sendiri dibandingkan pendapat orang lain. Ia juga mengatakan bahwa ia tetap pada pilihan sendiri, tanpa memperdulikan orang lain. Dalam hal 
mendidik anak subjek subjek $\mathrm{T}$ orang yang tegas pada pendapat sendiri tanpa melibatkan pendapat orang lain, karena menurutnya orang tua yang lebih mengerti keadaan anaknya. Ia juga orang yang konsisten, tanpa memperdulikan pendapat orang lain.

Dalam hal memutuskan sebuah pilihan, subjek D mengatakan bahwa ia lebih pada ke pendapat sendiri, meskipun terkadang ada beberapa hal yang ia rundingkan dengan istrinya terlebih dulu. Sedangkan dalam memutuskan sesuatu, subjek D cenderung berubah-berubah. Subjek D melihat terlebih dahulu apakah saran orang lain lebih baik dari padanya, jika saran orang lain lebih baik ia lebih mengikuti orang lain, hal ini yang membuat ia cenderung berubah-ubah dalam memutuskan sesuatu. Dalam hal mendidik anak, subjek D orang yang lebih mengikuti saran dari orang lain. Ia juga mengatakan bahwa ia orang yang cenderung berubah-ubah, jika masukan orang lain ia mengikuti masukan tersebut.

Subjek $\mathrm{H}$ merasa dirinya orang yang keras kepala, pada saat menentukan sebuah pilihan subjek $\mathrm{H}$ lebih pada pilihannya sendiri dibandingkan pilihan orang lain. Sedangkan dalam memutuskan sesuatu subjek $\mathrm{H}$ cenderung berubah-ubah tergantung dengan situasi yang ada. Dalam hal mendidik anak subjek $\mathrm{H}$ lebih pada pendapat sendiri dan terkadang subjek $\mathrm{H}$ melibatkan istri dalam hal mendidik anak. Subjek H mengatakan bahwa ia adalah orang yang cenderung berubah-ubah dan mudah terpengaruh dengan pendapat orang lain.Pada saat menentukan sebuah pilihan subjek $\mathrm{N}$ lebih pada pilihannya sendiri, tetapi jika pendapat orang lain lebih baik darinya ia memilih pendapat yang diajukan oleh orang lain dibandingkan pilihannya. Sedangkan dalam memutuskan sesuatu subjek $\mathrm{N}$ tetap pada pilihan yang ia pilih. Dalam hal mendidik anak, subjek $\mathrm{N}$ cenderung mengikuti pendapat orang lain. Subjek $\mathrm{N}$ mengatakan bahwa ia orang yang konsisten dan mengikuti apa yang menjadi kemauannya.

\section{SIMPULAN DAN SARAN}

Bedasarkan hasil penelitian, dapat disimpulkan bahwa dari kelima subjek memiliki faktor-faktor yang berbeda dalam proses penerimaan diri mereka. Faktor proses penerimaan yang dimiliki oleh $\mathrm{K}, \mathrm{D}, \mathrm{H}, \mathrm{N}$ adalah pemahaman tentang diri sendiri, harapan realistik, sikap-sikap anggota masyarakat yang menyenangkan, tidak adanya gangguan emosional yang berat, identifikasi dengan orang yang memiliki penyesuaian diri yang baik, adanya perspektif diri yang luas.

Faktor yang tidak dimiliki oleh $\mathrm{K}$ adalah pola asuh di masa kecil yang baik dan pengaruh keberhasilan yang dialami. Faktor yang tidak dimiliki dari $\mathrm{D}$ adalah hambatan di lingkungan, pengaruh keberhasilan yang dialami, konsep diri yang stabil, serta identifikasi dengan orang yang memiliki penyesuaian diri yang baik. $\mathrm{H}$ tidak memiliki faktor pengaruh keberhasilan yang dialami, pola asuh di masa kecil yang baik serta konsep diri yang stabil. $\mathrm{N}$ tidak memiliki faktor pengaruh keberhasilan yang dialami serta pola asuh dimasa kecil yang baik. Sedangkan hanya $\mathrm{T}$ yang memiliki semua faktor.

\section{Saran}

Dalam penelitian ini masih banyak kekurangan yang dimiliki, untuk itu bagi peneliti selanjutnya yang ingin melakukan penelitian dengan variabel yang sama diharapkan dapat lebih memperdalam teori teori yang digunakan dan memperdalam panduan wawancara sesuai dengan teori yang digunakan. Dalam penelitian ini, peneliti juga tidak memberikan kontrol pada karakteristik subjek mengenai usia dan lamanya subjek memiliki anak autisme, sehingga untuk penelitian berikutnya diharapkan dapat memberikan kontrol mengenai usia subjek dan lamanya subjek memiliki anak autisme untuk mengetahui apakah hasil tersebut mempengaruhi penerimaan diri pada orangtua dengan anak autisme. Bagi orang tua yang memiliki anak dengan autisme, diharapkan dapat memberikan kasih sayang serta perhatian dengan cara yang tepat, seperti mengikuti berbagai konseling, seminar, gathering workshop mengenai autisme. Untuk masyarakat, diharapakan dapat memberikan dukungan kepada kerabat, serta tidak menolak keadaan anak tersebut.

\section{DAFTAR PUSTAKA}

Ardilla, F., \& Herdiana, I. (2013). Penerimaan Diri pada Narapidana Wanita. Jurnal Psikologi Kepribadian dan sosial. Vol. 2(1), Februari 2013. 
Delphie, B. (2006). Pendidikan Anak Berkebutuhan Khusus dalam Seting Pendidikan Inklusi. Jakarta: Rineka Cipta.

Freedman, J. (2008). Autism. New York: The Rosen Publishing Group.

Agus, H. P. (2013). Jumlah Anak Berkebutuhan Khusus Di Indonesia Diperkirakan 4,2 Juta. Diunduh pada tanggal 05 Oktober 2016, dari http://m.detik.com/health/read/2013/07/ 17/184234/2306161/1301/jumlah-anakberkebutuhan-khusus-di-indonesiadiperkirakan-42-juta

Hurlock, E. B. (1974). Personality development. New Delhi: MC Graw-Hill.

Kumar, R. (2011). Research Methodology: A Step-By-Step Guide For Beginners Thrid Edition. London: SAGE Publications.

Erika, K. (2015). Autisme Di Indonesia Terus Meningkat. Diunduh pada tanggal 27 September 2016, dari http://m.okezone.com/read/2015/04/02/4 81/1128312/autisme-di-indonesia-terusmeningkat

Mangunsong, F. (2009). Psikologi dan pendidikan anak berkebutuhan khusus. Depok : LPSP3 Universitas Indonesia.

Meilinda, E. (2013). Hubungan Antara Penerimaan Diri dengan Konformitas Terhadap Intensi Merokok pada Remaja di SMK Istiqomah Muhammadiyah 4 Samarinda. eJournal Psikologi, Vol 1 (1), pp. 9-22.

NN. (2013). Penderita Autisme di Indonesia Terus Meningkat. Diunduh dari :

http://www.jpnn.com/read/2013/04/12/1 67064/Penderita-Autisme-di-IndonesiaTerus-Meningkat-(5 Oktober 2016).
NN. (2012). Jumlah Anak Berkebutuhan Khusus Meningkat. Diunduh dari: http://m.poskotanews.com/2013/07/19/j umlah-anak-berkebutuhan-khususmeningkat/ (27 September 2016).

Pancawati, R. (2013). Penerimaan Diri dan Dukungan Orangtua Terhadap Anak Autis. eJurnal Psikologi. Vol 1(1), pp.38-47.

Poerwandari, E, Kristi. (2011). Pendekatan Kualitatif untuk Penelitian Perilaku Manusia. Depok : LPSP3 UI

Edy, P. (2011). Mengenal Sekali Lagi Tentang Autisme. Diunduh dari: http://m.kompasiana.com/edyp/mengena 1-sekali-lagi-tentang autisme_5500a66ca33311c56f511c16 (25 September 2016)

Rachmayanti, S \& Zulkaida, A. (2007). Penerimaan Diri Orangtua Terhadap Anak Autisme dan Peranannya Dalam Terapi Autisme. Jurnal Psikologi. Vol.1(1), pp. 7-17.

Rizkiana, U. \& Retnaningsih. (2009). Penerimaan Diri pada Remaja Penderita Leukimia. Jurnal Psikologi. Vol. 2(2), pp. 114-122.

Smet, B. (1994). Psikologi kesehatan. Ahli bahasa: Bagus Wismanto. Jakarta : PT. Grasindo Persada.

Veague, H. B. (2010). Autism. Infobase Publishing.

White, B. (2011). Why Self Acceptance Is So Powerful. Bloomington: iUniverse.

White, B. (2012). Self Acceptance Process Bloomington Lunivers 